\title{
Evaluation of Risk Factors for Carbapenem-Resistant Klebsiella Pneumoniae Bacteremia
}

\author{
๑ Pınar Kıran,' ๑ Serap Gencer, ${ }^{2}$ ๑ Ayşe Batırel ${ }^{3}$
}

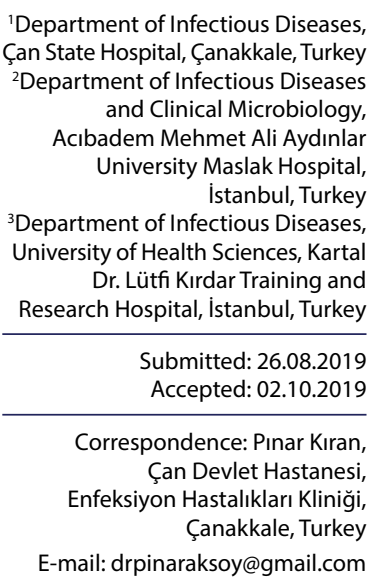

Q

Keywords: Bacteremia; carbapenem; Klebsiella pneumoniae; risk factors. Attribution-NonCommercial 4.0 International License.

\begin{abstract}
Objective: In recent years, carbapenem-resistant Klebsiella pneumoniae infections have become an important health problem in our country and all over the world. In this study, we aimed to identify the risk factors of carbapenem-resistant $K$. pneumoniae bacteremia.
\end{abstract}

Methods: Patients who suffered from Klebsiella pneumoniae bacteremia between December 2016 and May 2018 were included prospectively in this study. Patients were divided into groups according to carbapenem resistance and risk factors were analyzed under variable and multivariable logistic regression model.

Results: Of the fifty-three patients were included in this study, 27 patients infected with carbapenem-resistant $K$. pneumoniae and 26 patients infected with carbapenem-suspectible $K$. pneumoniae. Risk factors for carbapenem-resistant $K$. pneumoniae bacteremia according to univariate analysis were listed prior hospitalization $(p=0.043 ; O R=3.20 ; 95 \% \mathrm{Cl}$ : 1.04 $9.85)$, admission to intensive care unit ( $p=0.00 \mathrm{I}$; $O R=10.91$; $955 \mathrm{Cl}$ : $2.6 \mathrm{I}-45.6)$, use of beta-lactams/beta-lactamase inhibitor combination ( $p<0.00 \mathrm{I}$; $\mathrm{OR}=4 \mathrm{I} .67$; $95 \% \mathrm{Cl}$ : 7.57-229.2) and use of glycopeptides ( $p=0.00 \mathrm{I} ; \mathrm{OR}=7.92 ; 95 \% \mathrm{Cl}$ : $2.3 \mathrm{I}-27 . \mathrm{I})$. Before hospitalization $(p=0.016 ; O R=9.64 ; 95 \% \mathrm{Cl}: 1.54-60.46)$ and use of beta-lactams/beta-lactamase, inhibitor combination ( $p<0.00$; $O R=38.45$; $95 \% \mathrm{Cl}$ : 6.04-244.85) were identified as independent risk factors for carbapenem resistance in multivariate analysis.

Conclusion: According to our study, before hospitalization, the use of beta-lactams/betalactamase inhibitor combination was the major risk factor for carbapenem-resistant Klebsiella pneumoniae bacteremia.

\section{INTRODUCTION}

Bloodstream infections that arise from Gram-negative bacteria are infections that need to be diagnosed and treated quickly. In recent years, it has become an important problem due to increased antimicrobial resistance. [1] Klebsiella pneumoniae isolates lead to nosocomial infections, such as bloodstream infection, pneumonia, and urinary tract infection. ${ }^{[2]}$ In recent years, with increasing resistance rates in our country and all over the world, $K$. pneumoniae infections have been associated with high mortality and morbidity and have become an important health problem. ${ }^{[3,4]}$ Carbapenems are the most commonly used antibiotics for multi-drug resistant Enterobacteriaceae infections. Especially, they are the first treatment option for infections that arises from extended-spectrum beta-lactamase producing strains. ${ }^{[5]}$ Carbapenem resis- tance was first detected in 1997 in Klebsiella pneumoniae strains. $^{[6]}$ In September 200I, the OXA48 enzyme was defined in carbapenem-resistant Klebsiella pneumoniae isolates in our country for the first time. ${ }^{[7]}$ Nosocomial outbreaks with carbapenem-resistant strains have been reported all around the world. ${ }^{[8,9]}$

Among the members of the Enterobacteriacae family, the most susceptible bacterium which develops carbapenem resistance is $K$. pneumoniae. Since carbapenem-resistant isolates inhibit almost all beta-lactams, treatment options are quite limited in the infections caused by them and optimal treatment has not been determined for certain. Therefore, it is important to investigate the risk factors for the development of carbapenem resistance and to take necessary measures against these risk factors. In this study, we aimed to investigate the risk factors in carbapenem- resistant Klebsiella pneumoniae bacteremias. 


\section{MATERIALS AND METHODS}

Patients aged 18 and over who had Klebsiella pneumoniae growth in their blood cultures, and treated in the inpatient services of our hospital between December 2016 and May 2018, were included in this study. Data regarding age, gender, hospitalization in the intensive care unit, accompanying comorbidities, history of antibiotic use, hospitalization, operation and use of invasive tools within the last 90 days were recorded in the case report forms.

An automated system (VITEK2 Compact, bioMerieux, France) was used for determining bacteriological identification and carbapenem susceptibilities of Klebsiella pneumoniae isolate growing in blood culture, and also European Committee on Antimicrobial Susceptibility Testing (EUCAST) standards was used. ${ }^{[10]}$ Isolates with imipenem/ meropenem minimum inhibitory concentration (MIC) values of $\leq 2 \mathrm{mg} / \mathrm{L}$ and ertapenem MIC value of $\leq 0.5 \mathrm{mg} / \mathrm{L}$ were included in the carbapenem susceptible group. Isolates moderately sensitive or resistant to at least one of these antibiotics were included in the carbapenem- resistant group.

For statistical analysis, SPSS 22.0 Software (Chicago, IL, USA) program was used. Average, standard deviation, median, minimum, maximum, frequency and ratio values were used in the descriptive statistics of the data. The distribution of variables was measured by the KolmogorovSmirnov test. Mann-Whitney $U$ test was used in the analysis of quantitative independent data. In the analysis of qualitative independent data, the chi-square test was used, and when chi-square test conditions were not met, Fisher's exact test was employed. The effect level was investigated by univariate and multivariate regression analysis. $\mathrm{P}<0.05$ values were considered statistically significant.

\section{RESULTS}

Fifty-three patients with Klebsiella pneumoniae growth in blood culture between December 2016 and May 2018 were included in this study. Carbapenem resistance was found in 27 (50.9\%) of the isolates and 26 of them were susceptible to carbapenem. In addition, antibacterial resistance were detected against ceftriaxone in 42 (79.2\%), piperacillin/tazobactam in 31 (58.5\%), amikacin in 16 (30.2\%), gentamicin in $25(47.2 \%)$, cefepime in $28(52.8 \%)$ and ciprofloxacin in $32(60.4 \%)$ isolates.

Fifty-three cases included in our study consisted of 21 (39.6\%) female and 32 (60.4\%) male with a mean age of $58.4 \pm 15.8$ years. (median age, 60 years). The respective number of patients had a history of hospitalization $(n=28$ : $52.8 \%)$, operation $(n=22: 41.5 \%)$ within 30 , and antibiotic use within 90 days $(n=35: 66.0 \%)$. Twenty-five $(47.2 \%)$ patients had been hospitalized in the intensive care unit at the onset of bacteremia. Central catheter was detected in $27(50.9 \%)$, urinary catheter in $43(81.1 \%)$, and drainage catheter in $10(18.9 \%)$ patients, while $25(47.2 \%)$ patients were connected to mechanical ventilator. Comparison of demographic characteristics of the patients according to carbapenem resistance status is given in Table I.

The same isolate (Klebsiella pneumoniae) was grown in the urine culture of 21 , sputum / bronchoalveolar lavage culture in 5 , the blood culture obtained through central venous catheter in 3 , and wound culture, in 5 in patients. The foci of infection were urinary tract infection in 28 , respiratory tract infection in 8 , catheter-related bloodstream infection in 3, soft tissue infection in 5, and cholecystitis/ cholangitis in 5 cases. According to the results of univariate analysis hospitalization $(\mathrm{p}=0.043$; $\mathrm{OR}=3.20 ; 95 \% \mathrm{Cl}$ I.04$9.85)$, intensive care unit stay $(p=0.001 ; O R=10.91 ; 95 \%$ Cl 2.6I-45.6), beta-lactam/beta -lactamase inhibitor combination use $(p<0.001$; OR=41.67; 95\% Cl 7.57-229.2), glycopeptide use $(p=0.00 \mathrm{I}$; OR=7.92; $95 \% \mathrm{Cl} 2.3 \mathrm{I}-27 . \mathrm{I})$ all of them within 30 days were determined to be statistically significant risk factors for carbapenem resistance in Klebsiella pneumoniae bacteremias I (Table 2).

In the further multivariate analysis of the results, the use of carbapenem hospitalization ( $p=0.016 ; O R=9.64 ; 95 \%$ $\mathrm{Cl}$ 1.54-60.46), and use of beta-lactam/beta-lactamase inhibitor combination $(\mathrm{p}<0.00 \mathrm{I}$; OR $=38.45 ; 95 \% \mathrm{Cl} 6.04$ 244.85 ) within 30 days were found to be significant independent risk factors as for carbapenem resistance (Table 2).

\section{DISCUSSION}

In this study, which was carried out to determine risk factors due to increasing carbapenem resistance in Klebsiella pneumoniae strains, hospitalization, intensive care unit stay, use of beta-lactam/beta-lactamase inhibitor combination, and/or glycopeptide use within 30 days were determined as risk factors for the development of carbapenem resistance according to univariate analysis. Also, in our study, hospitalization and use of beta-lactam/beta-lactam inhibitor combination within 30 days were determined as independent risk factors for carbapenem resistance in advanced multivariate analysis.

As a risk factor for carbapenem resistance in Enterobacteriaceae infections in different studies, mostly emphasized and the important issue was the history of antibiotic use and hospitalization. ${ }^{[1-13]}$ In accordance with these findings, in our study, hospitalization history was determined as an independent risk factor for carbapenem resistance in both univariate and multivariate analyses. In our study, a statistically significant relationship was found between hospitalization in the intensive care unit, the use of glycopeptide and carbapenem resistance. In a case-control study conducted by Akgül et al., acute renal failure, steroid use, diarrhea, mechanical ventilation, presence of tracheostomy, urinary catheterization, central venous catheterization, nasogastric catheter use, emergency surgical intervention, total parenteral nutrition, hospitalization history, carbapenem, glycopeptide, colistin and piperacillin/tazobactam use were found to be risk factors for the development of carbapenem- resistant Klebsiella pneumoniae infection in univariate statistical analysis. 
Table I. Demographic characteristics of the patients with Klebsiella pneumoniae bacteremias according to their carbapenem resistance

\begin{tabular}{|c|c|c|c|}
\hline & $\begin{array}{c}\text { Carbapenem resistant } \\
\qquad(n=27)\end{array}$ & $\begin{array}{l}\text { Carbapenem sensitive } \\
\qquad(n=26)\end{array}$ & $\mathbf{p}^{*}$ \\
\hline Age, median (mean $\pm S D)$ & $62(61.3 \pm 16.6)$ & $59.5(55.3 \pm 14.6)$ & $0.197^{* *}$ \\
\hline Female/male & $10 / 17(37-63 \%)$ & II/I5 (42.3-57. 7\%) & 0.695 \\
\hline Hospitalization in the intensive care unit, $\mathrm{n}(\%)$ & $16(59.3)$ & $9(34.6)$ & 0.072 \\
\hline \multicolumn{4}{|l|}{ Comorbidities, n (\%) } \\
\hline Diabetes mellitus & $7(25.9)$ & $5(19.2)$ & 0.560 \\
\hline Chronic renal failure & $3(11 . I)$ & $4(15.4)$ & 0.646 \\
\hline Acute renal failure & $10(37)$ & II (42.3) & 0.695 \\
\hline Chronic liver disease & $0(0)$ & I (3.8) & 0.304 \\
\hline Malignancy & $9(33.3)$ & 14 (53.8) & 0.132 \\
\hline Coronary artery disease & $4(14.8)$ & $2(7.7)$ & 0.413 \\
\hline Hypertension & $14(51.9)$ & $8(30.8)$ & 0.119 \\
\hline Cerebrovascular disease & $3(I I . I)$ & I (3.8) & 0.317 \\
\hline Chronic pulmonary disease & $2(7.4)$ & $0(0)$ & 0.491 \\
\hline \multicolumn{4}{|l|}{ History, n (\%) } \\
\hline Antibiotic use within 90 days & $24(88.9)$ & II (42.3) & 0.000 \\
\hline Hospitalization within 30 days & $18(66.7)$ & $10(38.5)$ & 0.040 \\
\hline Surgery within 30 days & $12(44.4)$ & $10(38.5)$ & 0.659 \\
\hline \multicolumn{4}{|l|}{ Previous antibiotic use, $\mathrm{n}(\%)$} \\
\hline Cephalosporins & $3(11.1 \%)$ & I (3.8) & 0.317 \\
\hline Quinolones & $4(14.8)$ & $2(7.7)$ & 0.413 \\
\hline Glycopeptides & $19(70.4)$ & $6(23.1)$ & 0.001 \\
\hline Beta-lactam/beta-lactamase inhibitor combination & $25(92.6)$ & $6(23.1)$ & $<0.001$ \\
\hline \multicolumn{4}{|l|}{ Presence of invasive device, $n(\%)$} \\
\hline Central catheter & $17(63)$ & $10(38.5)$ & 0.074 \\
\hline Urinary catheter & $23(85.2)$ & $20(76.9)$ & 0.442 \\
\hline Mechanical ventilator & $16(59.3)$ & $9(34.6)$ & 0.072 \\
\hline Drainage catheter & $4(14.8)$ & $6(23.1)$ & 0.442 \\
\hline
\end{tabular}

*Chi-square test (Fisher's exact test); **Mann-Whitney U test. SD: Standard deviation.

Table 2. Univariate and multivariate analyses of risk factors for carbapenem resistance in Klebsiella pneumoniae bacteremias

\begin{tabular}{|c|c|c|c|c|c|c|}
\hline & \multicolumn{3}{|c|}{ Univariate analysis } & \multicolumn{3}{|c|}{ Multivariate analysis } \\
\hline & OR & $95 \% \mathrm{Cl}$ & $\mathbf{p}$ & OR & $95 \% \mathrm{Cl}$ & $\mathbf{p}$ \\
\hline Hospitalization within 30 days & 3.20 & $1.04-9.85$ & 0.043 & 9.64 & $1.54-60.46$ & 0.016 \\
\hline Hospitalization in the intensive care unit & 10.91 & $2.61-45.6$ & 0.001 & & & \\
\hline \multicolumn{7}{|l|}{ Previous use of antibiotics } \\
\hline Beta-lactam/beta-lactam inhibitor combination & 41.67 & $7.57-229.2$ & $<0.001$ & 38.45 & $6.04-244.85$ & $<0.001$ \\
\hline Glycopeptides & 7.92 & $2.31-27.1$ & 0.001 & & & \\
\hline
\end{tabular}

OR: Odds ratio; $\mathrm{Cl}$ : Confidence interval.

Nonusage of glycopeptide $(\mathrm{OR}=0.143 ; 95 \% \mathrm{Cl} 0.03 \mathrm{I}-$ $0.674 ; p<0.05)$, steroid $(\mathrm{OR}=0.244 ; 95 \% \mathrm{Cl} 0.072-0.822$; $p<0.05)$ and absence of tracheostomy $(O R=0.06 ; 95 \% \mathrm{Cl}$ $0.006-0.614 ; p<0.05)$ were determined as protective factors against the development of carbapenem resistance in multivariate regression analysis. ${ }^{[14]}$

In a meta-analysis that included sixteen studies, being in the hospital for a long time $(\mathrm{OR}=12.92)$, staying in the intensive care unit $(\mathrm{OR}=2.48)$, history of hospitalization $(O R=1.85)$, duration of hospitalization in the intensive care unit $(O R=4.58)$, organ transplant $(O R=2.01)$, steroid use $(O R=1.43)$, presence of central venous catheter $(O R=2.30)$, mechanical ventilation $(O R=2.54)$, presence of tracheostomy $(\mathrm{OR}=3.63)$, total parenteral nutrition $(O R=2.38)$, history of antibiotic use $(O R=3.31)$, including carbapenem $(O R=4.01)$, aminoglycoside $(O R=2.05)$, glycopeptide $(O R=2.40)$, quinolone $(O R=2.28)$, and an- 
tipseudomonal penicillin $(O R=2.67)$, have been identified as risk factors for carbapenem resistance in Klebsiella pneumoniae infections. ${ }^{[15]}$

In different studies, exposure to glycopeptides has been found to be an independent risk factor for carbapenem resistance in Klebsiella pneumoniae infections. ${ }^{[16,17]}$ In a study by Pultz et al. ${ }^{[18]}$ on mice, vancomycin and linezolid therapy have been shown to disrupt anaerobic intestinal flora and lead to colonization of Klebsiella pneumoniae. Colonization rate increased due to a high dose and prolonged vancomycin treatment time. The suppression of gram-positive bacteria in the intestinal flora with the use of glycopeptides leads to the proliferation of gramnegative bacteria. Although it is thought that mutations resulting from this rapid growth in gram-negative bacteria may increase the expression of genes associated with carbapenem resistance and contribute to the spread of carbapenemases. However, further studies are needed in this regard.

As in our study, the use of beta-lactam/beta-lactamase inhibitor combination $(\mathrm{OR}=4.765,95 \% \mathrm{Cl}$ I.508-15.055; $\mathrm{P}=0.008$ ) was found as a risk factor in both uni-, and multivariate analyses for carbapenem resistance in Klebsiella pneumoniae infections in a retrospective case-control study conducted in China. In addition, being hospitalized in the intensive care unit $(O R=15.486 ; 95 \% \mathrm{Cl} 3.175-75.541$; $\mathrm{p}<0.00 \mathrm{I})$, cephalosporin $(\mathrm{OR}=8.033 ; 95 \% \mathrm{Cl} \mathrm{I} .623-$ $39.763 ; p=0.01 \mathrm{I})$, and/or fluoroquinolone use $(O R=6.090$; $95 \% \mathrm{Cl} \mathrm{I.343-27.613;} \mathrm{p}=0.019)$ and the presence of urinary catheter $(O R=6.164 ; 95 \% \mathrm{Cl}$ I.847-20.578; $\mathrm{p}=0.003)$ were also identified as independent risk factors in this study. ${ }^{[19]}$ In another retrospective study conducted by Jiao et al. $^{[12]}$ uses of glycopeptide $(\mathrm{OR}=43.84 ; 95 \% \mathrm{Cl}$ I.73I I I.91; $p=0.020$ ), cefoperazone/sulbactam combination $(\mathrm{OR}=49.56 ; 95 \% \mathrm{Cl}$ I.42-1726.72; $\mathrm{p}=0.030)$, presence of tracheostomy $(\mathrm{OR}=677.82 ; 95 \% \mathrm{Cl} 2.76-1667 ; \mathrm{p}=0.020)$ were found to be independent risk factors for carbapenemresistant Klebsiella pneumoniae infection/colonization.

According to the annual report of Central Asian and Eastern European Surveillance of Antimicrobial Resistance (CAESAR) 2018, carbapenem resistance is increasing in $K$. pneumonae strains in our country; imipenem/meropenem resistance (moderately sensitive+resistant) was found in $38 \%$ and ertapenem resistance in $43 \%$ of the cases. ${ }^{[3]}$ Multidrug resistance rates also increased in $K$. pneumonae strains compared to the previous year (35\%) but were reported as 38 percent. In our study, carbapenem resistance was found in $50.8 \%$ of our K. pneumoniae isolates grown in blood culture.

In conclusion, carbapenem- resistant $K$. pneumoniae infections have become an important health problem in our country and in the world with increasing resistance rates. Therefore, considering the risk factors for carbapenem resistance, unnecessary use of antibiotics, especially the combination of glycopeptide, beta-lactam/beta-lactamase inhibitor, should be avoided. In addition, the possibility of carbapenem resistance should be taken into account when starting empirical antimicrobial therapy in bacteremias in patients who are hospitalized in the intensive care unit or who have a history of hospitalization.

\section{Ethics Committee Approval}

Approved by the local ethics committee (date: I3.12.2016, no: $2016 / 514 / 97 / 6)$.

Informed Consent

Prospective study.

Peer-review

Internally peer-reviewed.

Authorship Contributions

Concept: P.K., S.G., A.B.; Design: P.K., S.G., A.B.; Supervision: P.K., S.G., A.B.; Fundings: P.K., S.G., A.B.; Materials: P.K., S.G., A.B.; Data: P.K., S.G., A.B.; Analysis: P.K., S.G., A.B.; Literature search: P.K., S.G., A.B.; Writing: P.K.; Critical revision: P.K.

Conflict of Interest

None declared.

\section{REFERENCES}

1. Bakır M. Sepsisli Hastaya Acil Ünitede Yaklaşım. In: Özsüt H, editor. İnfeksiyon Acilleri. İstanbul: Türk İnfeksiyon Vakfi; 2002. p. 42-5.

2. Peleg AY, Hooper DC. Hospital-acquired infections due to gram-negative bacteria. N Engl J Med 2010;362:1804-13. [CrossRef]

3. World Health Organization Regional Office for Europe (WHO/ Europe). Central Asian and Eastern European Surveillance of Antimicrobial Resistance (CAESAR). Copenhagen: WHO/Europe. Available at: http://www.euro.who.int. Accessed Feb 11, 2020.

4. Patel G, Huprikar S, Factor SH, Jenkins SG, Calfee DP. Outcomes of carbapenem-resistant Klebsiella pneumoniae infection and the impact of antimicrobial and adjunctive therapies. Infect Control Hosp Epidemiol 2008;29:1099-106. [CrossRef]

5. Paterson DL. Resistance in gram-negative bacteria: Enterobacteriaceae. Am J Med 2006;119:S20-8. [CrossRef]

6. MacKenzie FM, Forbes KJ, Dorai-John T, Amyes SG, Gould IM. Emergence of a carbapenem-resistant Klebsiella pneumoniae. Lancet 1997;350:783. [CrossRef]

7. Poirel L, Héritier C, Tolün V, Nordmann P. Emergence of oxacillinase mediated resistance to imipenem in Klebsiella pneumoniae. Antimicrob Agents Chemother 2004;48:15-22. [CrossRef]

8. Rogers BA, Aminzadeh Z, Hayashi Y, Paterson DL. Country-to-country transfer of patients and the risk of multi-resistant bacterial infection. Clin Infect Dis 2011;53:49-56. [CrossRef]

9. Jean SS, Hsueh PR. High burden of antimicrobial resistance in Asia. Int J Antimicrob Agents 2011;37:291-5. [CrossRef]

10. The European Committee on Antimicrobial Susceptibility Testing. Breakpoint tables for interpretation of MICs and zone diameters. Version 8.1, 2018. Available from: http://www.eucast.org.

11. Asai N, Sakanashi D, Suematsu H, Kato H, Hagihara M, Nishiyama $\mathrm{N}$, et al. The epidemiology and risk factor of carbapenem-resistant enterobacteriaceae colonization and infections: Case control study in a single institute in Japan.J Infect Chemother 2018;24:505-9. [CrossRef]

12. Jiao Y, Qin Y, Liu J, Li Q, Dong Y, Shang Y, et al. Risk factors for carbapenem resistant Klebsiella pneumoniae infection/colonization and predictors of mortality: a retrospective study. Pathog Glob Health 2015;109:68-74. [CrossRef]

13. Giannella M, Trecarichi EM, De Rosa FG, Del Bono V, Bassetti 
M, Lewis RE, et al. Risk factors for carbapenem-resistant Klebsiella pneumoniae bloodstream infection among rectal carriers: a prospective observational multicenter study. Clin Microbiol Infect 2014;20:1357-62. [CrossRef]

14. Akgul F, Bozkurt I, Sunbul M, Esen S, Leblebicioglu H. Risk factors and mortality in the carbapenem-resistant Klebsiella pneumoniae infection: case control study. Pathog Glob Health 2016;110:321-5.

15. Liu P, Li X, Luo M, Xu X, Su K, Chen S, et al. Risk factors for carbapenemresistant Klebsiella pneumoniae infection: A meta-analysis. Microb Drug Resist 2018;24:190-8. [CrossRef]

16. Falagas ME, Rafailidis PI, Kofteridis D, Virtzili S, Chelvatzoglou FC, Papaioannou V, et al. Risk factors of carbapenem-resistant Klebsiella pneumoniae infections: a matched case control study. J Antimicrob Chemother 2007;60:1124-30. [CrossRef]

17. Kwak YG, Choi SH, Choo EJ, Chung JW, Jeong JY, Kim NJ, et al.
Risk factors for the acquisition of carbapenem-resistant Klebsiella pneumoniae among hospitalized patients. Microb Drug Resist 2005;11:165-9. [CrossRef]

18. Pultz NJ, Stiefel U, Donskey CJ. Effects of daptomycin, linezolid, and vancomycin on establishment of intestinal colonization with vancomycinresistant Enterococci and extended-spectrum-beta-lactamase-producing Klebsiella pneumoniae in mice. Antimicrob Agents Chemother 2005;49:3513-6. [CrossRef]

19. Wang Z, Qin RR, Huang L, Sun LY. Risk factors for carbapenem-resistant Klebsiella pneumoniae infection and mortality of Klebsiella pneumoniae infection. Chin Med J (Engl) 2018;131:56-62. [CrossRef]

20. Jiao Y, Qin Y, Liu J, Li Q, Dong Y, Shang Y, et al. Risk factors for carbapenemresistant Klebsiella pneumoniae infection/colonization and predictors of mortality: a retrospective study. Pathog Glob Health 2015;109:68-74. [CrossRef]

\section{Klebsiella Pneumoniae Bakteriyemilerinde Karbapenem Direnci İçin Risk Faktörlerinin Değerlendirilmesi}

Amaç: Son yıllarda artan karbapenem direnci ile birlikte Klebsiella pneumoniae enfeksiyonları ülkemizde ve tüm dünyada önemli bir sağlık problemi haline gelmiştir. Bu çalışmada, Klebsiella pneumoniae bakteriyemilerinde karbapenem direnci için risk faktörlerini belirlemeyi amaçladık.

Gereç ve Yöntem: Aralık 2016-Mayıs 2018 tarihleri arasında kan kültüründe Klebsiella pneumoniae üremesi olan hastalar ileriye yönelik olarak çalışmaya dahil edildi. Olgular karbapenem direnç durumuna göre gruplara ayrılarak; tek ve çok değişkenli regresyon modeli ile karbapenem direnci için risk faktörleri analiz edildi.

Bulgular: Çalışmaya dahil edilen 53 olgunun; 27'si karbapenem dirençli, 26'sı ise karbapenem duyarlı Klebsiella pneumoniae izolatı ile enfekte idi. Yapılan tek değişken analiz sonuçlarına göre; hastaneye yatış öyküsü [p=0.043; Odds ratio $(O R)=3.20$; \%95 güven aralığı (\%95 GA): I.04-9.85], yoğun bakım ünitesinde (YBÜ) yatıyor olmak ( $p=0.001$; $O R=10.91 ; \% 95 \mathrm{GA} 2.6 \mathrm{I}-45.6)$, beta-laktam/beta-laktam inhibitörü kombinasyonu kullanımı ( $\mathrm{p}<0.00 \mathrm{I}$; OR=4I.67; \%95 GA 7.57-229.2), glikopeptid kullanımı ( $\mathrm{p}=0.00 \mathrm{I}$; OR=7.92; \%95 GA 2.3I-27.I) Klebsiella pneumoniae bakteriyemilerinde karbapenem direnci için istatistiksel olarak anlamlı bulundu. Çok değişkenli analiz sonucunda ise; hastaneye yatış öyküsü ( $p=0.016$; OR=9.64; \%95 GA: I.54-60.46), beta-laktam/beta-laktam inhibitörü kombinasyonu kullanımı ( $<<0.00 I$; OR=38.45; \%95 GA 6.04-244.85) karbapenem direnci açısından anlamlı bağımsız risk faktörü olarak saptandı.

Sonuç: Yaptı̆̆ımız çalışmada, hastanede yatış öyküsü, beta-laktam/beta-laktamaz inhibitörü kombinasyonu kullanımı Klebsiella pneumoniae bakteriyemilerinde karbapenem direnci için en önemli risk faktörü olarak bulunmuştur.

Anahtar Sözcükler: Bakteriyemi; karbapenem; Klebsiella pneumoniae; risk faktörleri. 